\title{
Strategic Environment, Strategist, and Strategy
}

\section{Lingkungan Strategis, Strategist (Ahli Siasat), dan Strategi}

\author{
Asep Kamaluddin Nashir \\ Universitas Pembangunan Nasional "Veteran" Jakarta \\ Yugolastarob Komeini \\ Sekolah Tinggi Intelijen Negara \\ Hesti Rosdiana \\ Universitas Pembangunan Nasional "Veteran” Jakarta
}

\begin{abstract}
ABSTRAK
Tulisan ini bertujuan untuk menjelaskan irisan dan keterkaitan erat antara lingkungan strategis, strategist, dan strategi dalam perkembangan isu-isu keamanan internasional. Selain itu, faktor national will setiap negara memberikan pemahaman berbeda tentang perspektif strategis dan perumusan strategi yang dihasilkan. Hasil dari tulisan ini menjelaskan bahwa lingkungan strategis menjadi preferensi strategist atau para pengambil kebijakan dalam merumuskan kebijakan atau strategi, dengan mempertimbangkan national will untuk menghadapi perkembangan lingkungan strategis. Dengan kata lain, identifikasi lingkungan strategis bagi aktor negara menjadi sebuah keharusan untuk menjamin tercapainya kepentingan nasional. Identifikasi tersebut berkonsekuensi pada pemahaman strategist dalam menyusun strategi untuk mencapai kepentingan nasional sebuah negara.
\end{abstract}

Kata-kata kunci: Lingkungan strategis, National Will, Natuna, Indo-Pasifik

This paper aims to explain the links between the strategic, strategic, and strategic environments in the development of international security issues. Furthermore, we seek to explain why a country's national will provide a different understanding of the resulting strategic perspective and strategy formulation. The results of this paper explain that the strategic environment becomes the preference of strategists or policymakers in formulating policies or strategies, taking into account the national will, to adapt to the development of the strategic environment. In other words, identifying the strategic environment for state actors is a must to ensure the achievement of national interests. This identification has consequences on strategic understanding in formulating strategies to achieve the national interest of a country.

Keywords: Strategic environment, National Will, Natuna, Indo-Pacific 
Tulisan ini bertujuan untuk menganalisis keterkaitan antara tiga variabel dalam bidang keamanan di dalam beberapa isu -isu keamanan, yaitu perkembangan lingkungan strategis, strategis (ahli siasat) atau pengambil kebijakan, dan strategi sebagai means bagi negara dalam memenuhi kepentingan nasional. Menariknya, keterkaitan antara lingkungan strategis, strategis, dan strategi bagi setiap negara (aktor) memiliki perbedaan. Hal itu dipengaruhi oleh national will. Karena itu, paper ini menekankan pada bagaimana karakter national will sebuah negara berperan dalam menjelaskan keterkaitan variabel lingkungan strategis, strategis, dan strategi.

Identifikasi strategist (ahli siasat) atau pemimpin dan pengambil kebijakan terhadap perkembangan lingkungan strategis, baik internal maupun eksternal, memberikan strategic value bagi strategist untuk merumuskan strategi yang tepat dalam mencapai kepentingan. Dengan kata lain, lingkungan strategis mengedukasi cara berpikir strategis. Dalam konteks negara, strategis adalah semua tentang bagaimana (konsep atau cara) kepemimpinan akan menggunakan kekuatan (sumber daya atau sarana) yang tersedia bagi negara untuk melakukan kontrol atas pengaturan keadaan dan lokasi geografis untuk mencapai tujuan sesuai dengan kebijakan negara.

Di sisi lain, strategi menjadi cara untuk mengungkapkan logika dalam istilah-istilah yang rasional dan linier - tujuan, kekuatan, dan cara. Strategi, kemudian, memberikan arahan bagi negara, yang berupaya memaksimalkan hasil positif dan meminimalkan hasil negatif, ketika negara bergerak melalui lingkungan yang kompleks dan cepat berubah ke masa depan (Yarger 2006). Strategi mengasumsikan bahwa masa depan tidak dapat diprediksi, namun lingkungan strategis dapat dipelajari, dinilai, dan, pada tingkat yang berbeda, diantisipasi (Yarger 2006). Pengembangan strategi menginformasikan kebijakan; kebijakan harus menyesuaikan diri dengan realitas lingkungan strategis dan batas kekuasaan. Dengan kata lain, lingkungan strategis menjadi referensi bagi perumusan kebijakan sebagai bagian dari strategi.

Keterkaitan antara perkembangan lingkungan strategis dan keterlibatan pemimpin negara atau para pengambil kebijakan (strategist/ahli siasat), terutama dalam merumuskan kebijakan (strategi) menjadi pembahasan yang menarik, terutama sebagai sebuah gambaran teoritis sekaligus praktis dalam melakukan analisa kasus. Dalam berbagai literatur, cara pandang 
konvensional dalam membahas strategi, terlihat dalam beberapa literatur, seperti Barry Buzan dan Bradley S Klein. Buzan (1987), dalam bukunya yang berjudul An Introduction to Strategic Studies: Military Technology and International Relations, memberi penekanan pada strategi yang difokuskan pada bidang militer. Persoalan "power" dalam bidang militer menjadi fokuS utama pembahasan mengenai esensi strategi. Kausalitas antara hubungan konflik antar negara menjadi dasar bagi sebuah negara dalam mempersiapkan kekuatan militer. Pembahasan mengenai penangkalan, perlombaan senjata, dan kajian keamanan lingkup persenjataan dibahas secara komprehensif. Selain itu, persoalan teknologi militer dan penyebarannya menjadi poin utama di dalam pembahasan yang mempengaruhi perkembangan konflik antar negara dan kemampuan negara dalam isu-isu studi strategis.

Hampir serupa, Klein (1994) dalam bukunya yang berjudul Strategic Studies and World Order, menekankan pada pembahasan tentang perimbangan militer dan persenjataan konvensional, seperti senjata nuklir. Pembahasan tentang persenjataan ditujukan untuk membahas kondisi global, yaitu perang dan damai. Persenjataan sebagai variabel yang mempengaruhi kondisi global dalam pembahasan perang dan damai, secara teknis, ditekankan pada pembahasan secara spesifik tentang hubungan antar negara yang berada pada aliansi, keamanan, dan penangkalan. Senjata nuklir yang digunakan sebagai strategi penangkalan, mendorong perkembangan aliansi serta hubungan politik yang mempengaruhi keamanan global, baik kondisi menuju perang atau mengarah pada perdamaian global.

Pembahasan mengenai strategic studies yang lebih berkembang dengan menekankan pada perkembangan isu baru di dunia keamanan diulas dengan baik oleh Baylis dan Wirtz atau Gray dan Sloan. Tulisan Baylis dan Wirtz (2002) yang berjudul Strategy in the Contemporary World: An Introduction to Strategic Studies menekankan pada agenda baru di bidang keamanan dan strategi sebagai bentuk perubahan karakter ancaman yang mempengaruhi keamanan global dan lingkup pembahasan strategi yang lebih modern. Pembahasan utama dalam tulisan Baylis dan Wirtz menekankan pada kritik terhadap studi strategis yang hanya menitikberatkan pada peran sentral kekuatan militer. Pembahasan mengenai strategist dan kebijakan dibahas secara singkat sebagai bagian dari perluasan bidang studi strategis yang tidak hanya berkutat pada bidang militer. Strategist membahas 
tentang persoalan keamanan negara yang tidak hanya terdapat pada studi strategis saja, namun lingkup keamanan yang lebih luas (security studies).

Lingkup keamanan yang lebih luas tidak hanya membahas tentang perang dan strategi, namun perkembangan isu dalam hubungan internasional mendorong strategi menjadi bagian dari pembahasan studi keamanan mengingat persoalan kekuatan militer dipengaruhi oleh bidang politik, kebijakan luar negeri, dan persoalan kemanusiaan, meski pembahasan mengenai militer tidak dapat ditinggalkan begitu saja, mengingat peran sentral militer sangat krusial dalam mencapai tujuan-tujuan politik negara dan kondisi sosial secara global. Dengan kata lain, Baylis dan Wirtz menekankan pada cara pandang dan berpikir strategis yang merefleksikan perkembangan hubungan internasional.

Gray dan Sloan (2013) dalam bukunya yang berjudul Geopolitics, Geostrategy, and Strategy, menjelaskan bahwa konfigurasi geografi menjadi refleksi bagi para pengambil kebijakan untuk memanfaatkan peluang. Eksploitasi konfigurasi geografi dapat dilakukan dengan menerapkan strategi yang tepat. Dengan kata lain, faktor geografi mempengaruhi langkah politik yang dirumuskan pengambil kebijakan untuk memilah kepentingan dan bersikap realistis dengan kepentingan politik yang disesuaikan dengan formulasi strategi.

Gray dan Sloan menjelaskan faktor geografi sebagai salah satu bagian dari lingkungan strategis yang memiliki kaitan dan irisan jelas dengan kepentingan negara, serta peranan ahli strategi dalam memenuhi kepentingan nasional. Lebih spesifik, pembahasan mengenai geografi digambarkan sebagai bagian dari konstelasi penyebaran kekuatan militer sebagai theater of military action. Cara pandang geografi sebagai wilayah bermain kekuatan militer ini yang kemudian mengawali eksploitasi konfigurasi geografi dalam memunculkan penggunaan wilayah laut untuk sea power dan udara untuk penggelaran air power.

Amerika Serikat (AS) dan Uni Soviet merupakan sekutu bersama Perancis dan Inggris untuk menghadapi Jerman dalam perang dunia II. Interaksi antara Amerika Serikat dengan Uni Soviet berubah menjadi permusuhan pasca perang dunia II, tepatnya ketika tatanan kutub hegemoni berada diantara kompetisi kekuatan AS Vs. Uni Soviet dalam kompetisi perang dingin (Gray 
2006). Bagi AS, tujuan menjadi negara hegemoni, mengharuskan negara tersebut untuk bersaing dengan Uni Soviet. Faktor ideologi komunis, aktor (Uni Soviet), aliansi, posisi negara-negara dunia ketiga dalam persaingan ideologi dan militer, peningkatan kekuatan militer Uni Soviet, pemetaan kekuatan aliansi, baik internal AS maupun pihak oposisi, pengerahan sumber daya, dinamika konstelasi politik global, penggelaran rudal di Kuba oleh Uni Soviet (geostrategi), merupakan perkembangan lingkungan strategis yang mempengaruhi AS dalam mencapai kekuasaan global. Identifikasi dan pemetaan lingkungan strategis tersebut menjadi preferensi AS dalam merumuskan strategi. Dengan kata lain, kemampuan pemimpin AS dalam mengidentifikasi lingkungan strategis, menjadi acuan bagi negara tersebut dalam merumuskan strategi.

\section{Ahli Siasat, Strategi, dan Lingkungan Strategis}

Frank, dalam tulisannya yang berjudul The Czech Republic Security Environment, menjelaskan pola dalam memahami lingkungan strategis sebuah negara dengan membagi pada lingkup geografisnya. Masing-masing level ini memiliki dimensi teritorial dan dinamis yang menggambarkan ruang lingkup yang dapat ditentukan secara geografis dan tingkat pengaruh negara terhadap perkembangan. Berdasarkan lingkup teritorialnya, lingkungan strategis dapat dibedakan menjadi tiga jenis (Frank 2003). Pertama, immediate security environment, yang mencakup negara-negara yang bertetangga yang memiliki batasbatas teritorial langsung, yang dapat memberikan dampak situasi krisis. Kedua, close security environment, yang meliputi kawasan regional yang lebih luas. Ketiga, wide security environment, yang mencakup negara-negara kuat (major power) regional dan global. Sementara itu, lingkungan strategis dapat dipahami, seperti yang dijelaskan W. Michael Guilliot, yaitu:

"One construct includes four distinct, interrelated parts: the national security, domestic, military, and international environment. Within the strategic environment, one must consider many factors and actors. This construct is neither a template nor checklistnor a recipe for perfection. The framework recognizes the fact that one must conceptualize in both political 
and military realms. Additionally, it illustrates how the strategic environment is interrelated, complementary, and contradictory." (Guilliot 2003)

Kerangka pemikiran ini memberikan keleluasaan dalam melihat atmosfer politik dan militer sebagai bagian analisis aktor dan faktor yang mempengaruhi hubungan bernegara, khususnya bidang politik dan militer. Persaingan global antara AS dan Uni Soviet dalam menjadi kekuatan global, menjelaskan (1) penggalangan kekuatan ofensif Uni Soviet dengan memanfaatkan negara tetangga AS, yaitu Kuba. (2) Dinamika pengerahan kekuatan dan konflik regional di wilayah Eropa. Eropa terbagi menjadi dua bagian, yaitu Eropa Timur sebagai basis kekuatan Uni Soviet, dan Eropa Barat sebagai basis kekuatan AS, bersama Inggris dan negara Eropa lainnya. (3) Persaingan global kedua negara terlihat pada dampak penyebaran konflik yang juga terjadi di Asia (perang ideologi di Vietnam dan Korea) (Allison 1971; Gray 2006).

Dalam situasi seperti itu, ahli siasat harus memiliki kemampuan untuk memahami hubungan di dalam lingkungan ia berada, dan menerapkannya dalam pengembangan strategi (Yarger 2006). Dalam lingkungan strategis, ahli siasat perlu mempertimbangkan banyak faktor dan aktor, namun konstruksi terhadap aktor dan faktor tidak menjelaskan template atau susunan daftar isi dalam sebuah buku, dan bahkan resep makanan yang bersifat statis atau sudah terpola (Guillot 2003). (Lihat gambar 1).

\section{Gambar 1}

Lingkungan Strategis sebagai Preferensi Ahli Siasat

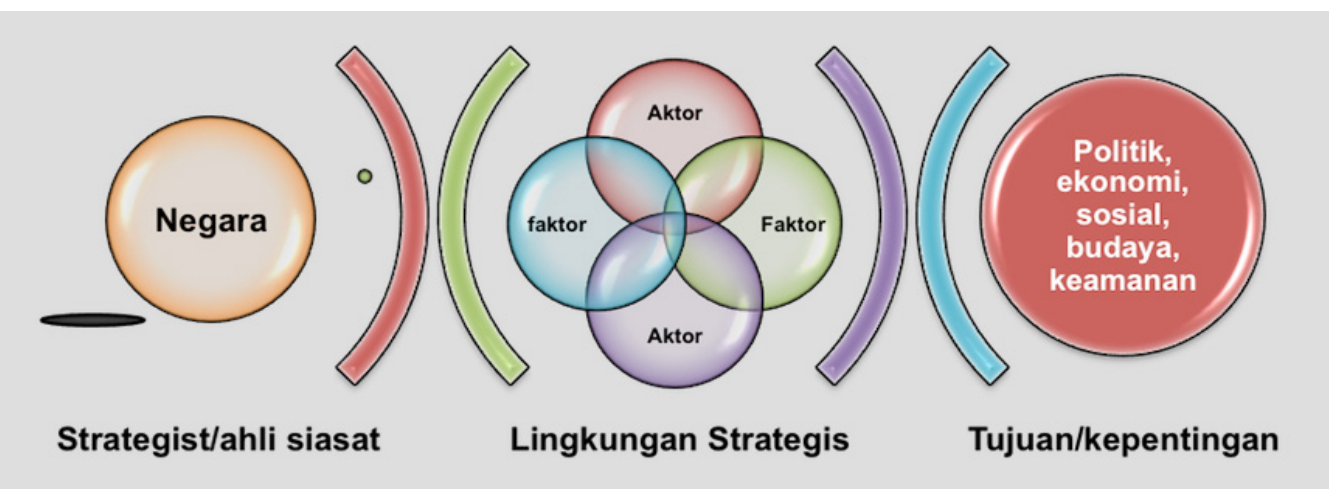

Sumber: diolah penulis 
Sementara itu, peran ahli siasat dikategorikan ke dalam 3 karakter, yaitu pemimpin (negara), praktisi, dan ahli teori. Masing-masing peran ini membutuhkan keterampilan dan kompetensi yang berbeda. Pemimpin memberikan visi, inspirasi, keterampilan organisasi, arahan, dan dorongan pribadi yang diperlukan untuk memungkinkan orang lain bertindak dengan cara yang terfokus dan koheren. Praktisi memahami level strategi dan hubungannya secara menyeluruh dan mengembangkan strategi. Dia menerjemahkan pedoman kebijakan secara luas menjadi strategi terpadu yang mengarah pada keberhasilan kebijakan. Ahli teori mengembangkan konsep-konsep teoretis melalui studi dan pemikiran serta mengajar dan membimbing orang lain (Yarger 2006; Mintzberg 2007).

Dalam berbagai literatur, berbagai contoh pemimpin, baik pemimpin negara seperti John F. Kennedy, panglima perang seperti Baron Antoine Henri De Jomini dan Carl Von Clausewitz, dan tokoh-tokoh berpengaruh di kerajaan, seperti era Sun Tzu dan Niccolo Machiavelli, menjelaskan esensi strategi dan bahkan menjadi contoh dan inspirasi para pemikir strategis di era terkini (Mintzber 2007; Bondanella 2005; Price 2008). Contoh-contoh para pemikir strategis di atas menjelaskan bagaimana peran ahli siasat dalam memenangkan persaingan, peperangan ataupun pertempuran.

\section{National Will dan Perumusan Strategi}

Pembahasan tentang lingkungan strategis, ahli siasat, dan strategi dapat dilakukan dengan menekankan pada keterkaitan dan irisan masing-masing konsep dengan menekankan pada hubungan kausalitas antar ketiganya. Dengan kata lain, Secara mendasar, lingkungan strategis merupakan situasi yang menjelaskan berbagai aktor dan faktor yang mempengaruhi cara pandang dan perilaku ahli siasat dalam mencapai kepentingan. Lingkungan strategis menjadi preferensi dalam merumuskan kebijakan atau strategi. Sementara, ahli siasat adalah pemimpin/para pengambil kebijakan negara, praktisi, akademisi yang berpikir, merumuskan dan menjalankan strategi. Di sisi lain, strategi merupakan metode (method) yang dirumuskan dan disusun, untuk kemudian digunakan ahli siasat dalam mencapai tujuan atau kepentingan. (Lihat gambar 2) 


\section{Gambar 2}

\section{Keterkaitan Lingkungan Strategis, Strategist, dan Strategi dalam Mencapai Tujuan}

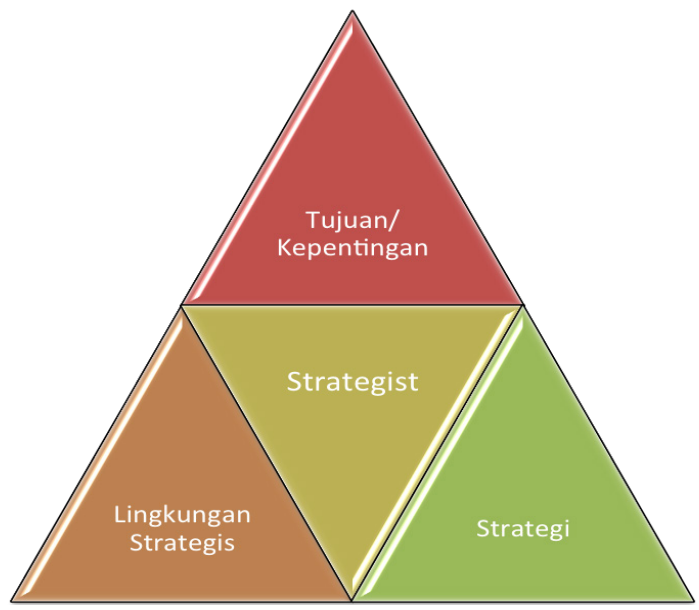

Gambar diatas menjelaskan peran ahli siasat dalam menentukan kepentingan yang menjadi target tujuan, serta refleksi dalam mengidentifikasi lingkungan strategis untuk kemudian menjadi preferensi dalam merumuskan strategi mencapai kepentingan. Tulisan ini mencoba mengimplementasikan konsep lingkungan strategis, strategis, dan strategi dalam beberapa kasus untuk menjelaskan gambaran keterkaitan ketiganya dalam isu-isu keamanan. Selain itu, pembahasan national will sebuah negara menjadi perlu dianalisis mengingat national will menjadi dasar perilaku negara dalam merespon perkembangan lingkungan strategis dan perumusan kebijakan negara sebagai sebuah strategi. Terlebih lagi, persoalan ahli siasat yang berperan penting, terutama pemimpin negara dalam interaksi konflik, menjadi sebuah variabel penting yang dibahas. Namun, faktor national will menjadi faktor yang seringkali diabaikan, meski berperan besar dalam mendominasi perumusan kebijakan negara.

National will direfleksikan melalui keputusan politik yang dibuat negara dengan menggunakan seluruh aspek kekuatan nasional untuk mencapai kepentingan politik (McNerney 2018). Secara spesifik, faktor national will mempengaruhi perumusan kebijakan yang dilakukan oleh pengambil kebijakan untuk dalam memformulasikan kebijakan sebagai sebuah strategi. (Lihat gambar 3) 


\section{Gambar 3}

National Will Framework

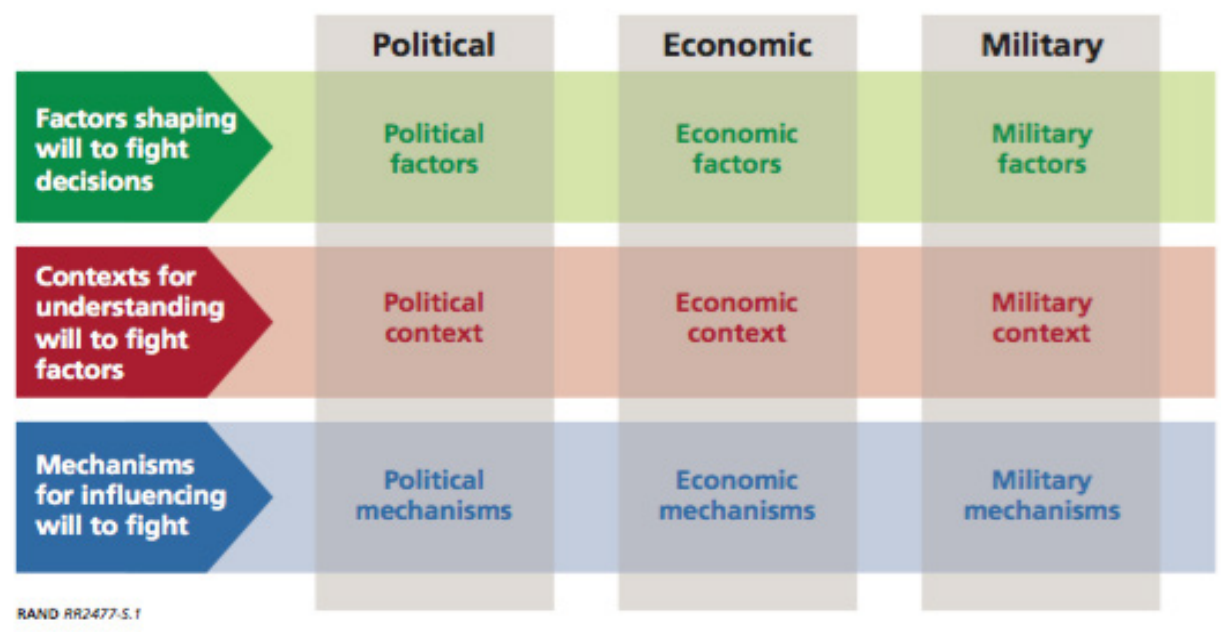

Sumber: diolah dari McNerney, Michael J. (2018)

Secara pembagian, national will sebuah negara dapat dilihat dari 3 faktor yang menjadi target kepentingan sekaligus perilaku negara, seperti pada gambar di atas. Pembagian bidang politik, ekonomi, dan militer merupakan variabel yang paling mempengaruhi kemampuan negara dalam memenuhi kepentingan nasional sekaligus bidang-bidang yang paling dipertimbangkan dalam merumuskan berbagai kebijakan nasional.

National will sebuah negara menentukan perilaku negara untuk seberapa jauh terlibat atau menghindari konflik dengan negara lain. Hal itu dapat dilihat dari berbagai kebijakan politik, ekonomi, dan militer sebuah negara dalam isu-isu yang mempengaruhi kepentingan politik, ekonomi dan militer. Meskipun tidak bersifat komprehensif, namun nilai-nilai national will setidaknya dapat dipahami melalui berbagai perencanaan kebijakan negara yang akan diimplementasikan melalui kebijakan dalam mewujudkan keamanan nasional, meski hal itu bergantung pada kemampuan pemimpin dalam memahami konflik dan potensi konflik. 
Namun, secara operasional, national will sebuah negara tercermin melalui (McNerney 2018): (1) variabel politik membahas karakteristik pemerintah dan perubahan persepsi, hubungan, penilaian, dan motivasi ideologis pemerintah selama konflik; (2) variabel ekonomi membahas karakteristik ekonomi negara dan pengaruh yang berubah terhadap ekonomi (tekanan dan bantuan) selama konflik; dan (3) variabel militer membahas karakteristik militer dan perubahan faktor militer yang mempengaruhi pengambilan keputusan pemerintah selama konflik.

Dengan kata lain, national will menjelaskan perencanaan negara dalam memenuhi kepentingan nasional. Perencanaan tersebut mendorong perilaku politik, ekonomi, dan militer sebuah negara untuk menentukan perkembangan kebijakan dan perilaku ketika muncul sebuah isu atau ketika negara terlibat di dalam sebuah isu, yang berpotensi mempengaruhi kepentingan nasional. Berikut model faktor national will yang menjadi pertimbangan pengambil kebijakan dalam menentukan strategi berdasarkan perkembangan lingkungan strategis (lihat gambar 4).

\section{Gambar 4}

\section{Model Faktor National Will dalam Perumusan Strategi}

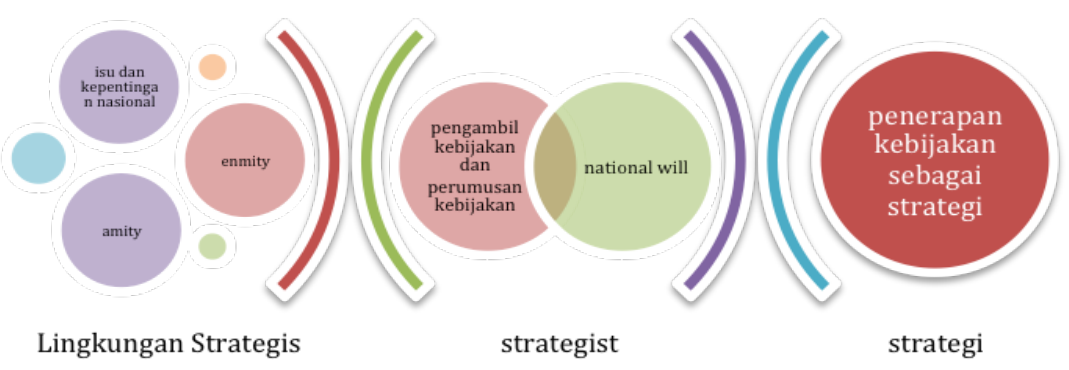

Sumber: diolah penulis 


\section{Isu dan Kasus: Indonesia dan Laut Natuna Utara}

Dalam kasus Indonesia di Laut Cina Selatan, perkembangan lingkungan strategis di wilayah tersebut dipengaruhi oleh perebutan wilayah oleh beberapa negara-negara di Asia Tenggara dengan Cina. Masing-masing negara mengklaim kedaulatan di wilayah yang diperebutkan. Cina, sebagai negara dengan ambisi besar untuk menjadi penantang hegemoni AS, memiliki kebijakan nine-dash line, yang meliputi hampir seluruh wilayah LCS (Yuan 2012).

Persoalannya, terdapat ketidakpastian dan kompleksitas masalah yang dihadapi Indonesia, meski tidak menjadi bagian dari konflik utama dalam perebutan wilayah, ketidakpastian ini mendorong Indonesia pada situasi dilema kebijakan nine-dash line tersebut. Cakupan nine-dash line, justru melingkupi Zona Ekonomi Eksklusif (ZEE) Indonesia di Natuna. Kebijakan geopolitik dan geostrategi Cina, klaim wilayah antar negara, adu pengaruh kekuatan antara Cina-AS, aliansi AS dengan Vietnam dan Filipina, faktor sejarah Cina di LCS, dan isu kebebasan navigasi, serta pelanggaran kedaulatan wilayah di ZEE Indonesia menjelaskan ketidakpastian perkembangan perdamaian di kawasan, sekaligus menekankan pada kompleksitas faktor dan hubungan antar aktor di wilayah tersebut.

Situasi kompleks dan tingkat ketidakpastian yang tinggi, serta instabilitas dinamika hubungan konflik, pelanggaran wilayah, dan pencurian sumber daya laut menjadi karakter utama lingkungan strategis di LCS. Indonesia memiliki kepentingan keamanan dalam menjaga keutuhan wilayah, sekaligus menjaga sumber daya laut di ZEE di wilayah Natuna.

Di LCS, sekitar wilayah Natuna, kebijakan nine-dash line Cina yang mencakup hampir semua wilayah Laut Cina Selatan. Menurut Cina, wilayah tersebut mencerminkan "kebenaran" yang berasal dari pengalaman ekspedisi survei bersejarah, penangkapan ikan, dan kegiatan angkatan laut sejak abad ke-15. Klaim atas wilayah ini juga tercermin dalam peta tahun 1947 yang ditegaskan kembali dalam peta resmi yang diterbitkan oleh Negara Cina dari tahun 1949 sampai dengan sekarang (Chapman 2014). LCS menjadi sumber ketegangan geopolitik yang semakin diperdebatkan karena 
nilai strategisnya sebagai rute perdagangan internasional, serta keberadaan sumber daya minyak dan gas alam yang berpotensi besar (Chapman 20141; Korkut 2017).

Di sisi lain, Natuna adalah wilayah Indonesia yang menonjol dan cukup ramai dibicarakan, terutama ketika kehadiran Cina yang semakin ofensif di wilayah LCS. Wilayah Natuna yang berdekatan dengan LCS membuat wilayah tersebut sangat rentan, terutama ketika Cina mengklaim kepemilikan Natuna. Untuk itu, Indonesia menyadari bahwa ancaman kedaulatan sedang terjadi saat ini. Bentuk ancaman kedaulatan ini membutuhkan penanganan. Langkah-langkah geostrategi, diperlukan untuk mengamankan kedaulatan dan melindungi sumber laut dilakukan dengan menghindari tindakan konfrontatif.

Selain itu, ancaman non-tradisional juga menjadi bagian dari situasi yang memperkeruh situasi keamanan di Natuna. Sebuah kapal penangkap ikan Tiongkok yang masuk ke perairan Natuna, ditangkap oleh kapal patroli Indonesia. Namun, sebuah kapal patroli Cina dengan cepat muncul dan turun tangan untuk membebaskan kapal nelayan Cina. Menteri Kelautan dan Perikanan Indonesia mengumumkan hal ini kepada pers dan memprotes ke Cina. Kementerian Luar Negeri Cina menanggapi dengan menyatakan bahwa para nelayan Tiongkok melakukan pekerjaan rutin mereka di "wilayah penangkapan ikan tradisional" (Suryadinata 2017). Istilah "wilayah memancing tradisional" muncul sebagai pembenaran atas kebijakan nine-dash line Cina yang berdasarkan faktor historis.

Batas wilayah yang tidak jelas menyebabkan nelayan Cina memasuki perairan ZEE Indonesia. Hal itu tidak hanya mempengaruhi hilangnya sumber daya laut, tetapi juga hak berdaulat Indonesia di mana klaim Cina, melalui nine-dash Line, di ZEE atau perairan Natuna. Perkembangan tersebut kemudian menjadi preferensi dan dasar bagi para pengambil kebijakan Indonesia menentukan perumusan kebijakan atau strategi dalam menghadapi Cina. Strategi yang dirumuskan bertujuan untuk mempertahankan dan menjaga keamanan Indonesia dari ancaman yang berasal dari Cina, berupa pelanggaran keutuhan wilayah dan tindakan penangkapan ikan ilegal yang merugikan negara.

Berdasarkan lima pilar utama yang akan membuat Indonesia mewujudkan cita-citanya sebagai poros maritim dunia, terlihat 
bahwa national will Indonesia memang tidak mengarahkan Indonesia untukterlibat dalam konflik, bahkan cenderung berusaha untuk menghindari terjadinya konflik, dengan mendorong berbagai bentuk kerjasama. Hal tersebut dapat dilihat dari kelima pilar tersebut, terutama pilar keempat, yaitu: (1) membangun kembali budaya bahari Indonesia; (2) komitmen memelihara dan mengelola sumber daya laut dengan fokus membangun kedaulatan pangan laut melalui pengembangan industri perikanan dengan menempatkan nelayan sebagai pilar utama; (3) komitmen untuk mendorong pembangunan infrastruktur dan konektivitas maritim dengan membangun tol laut, pelabuhan laut, industri logistik dan perkapalan serta wisata bahari; (4) diplomasi maritim Indonesia mengajak semua mitra untuk bekerja sama di bidang kelautan guna menghilangkan sumber konflik di laut, seperti illegal fishing, pelanggaran kedaulatan, sengketa wilayah, pembajakan, dan pencemaran laut; dan (5) Indonesia wajib membentuk kekuatan laut untuk menjaga kedaulatan dan kekayaan maritim serta menjaga keselamatan navigasi dan keamanan maritim.

Berdasarkan pertimbangan national will dan pemahaman pengambilkebijakanterhadap perkembanganlingkunganstrategis, maka langkah strategis para pengambil kebijakan Indonesia di bawah pemerintahan Joko Widodo (Jokowi) yang mengusung kebijakan Poros Maritim mengedepankan perumusan kebijakan yang menekankan pada kebijakan diplomasi. Diplomasi yang menjadi bagian dari agenda Poros Maritim Dunia, mempertegas peran diplomasi dalam menghadapi persoalan-persoalan maritim Indonesia.

Diplomasi yang dilakukan oleh Indonesia berujung pada pengumuman resmi nama Laut Natuna Utara sesuai dengan standar yang ditetapkan oleh the International Hydrographic Organization and the provisions of the Electronic Navigational Chart, yang menegaskan kedaulatan Indonesia dari perspektif hukum internasional di perairan Natuna, Indonesia. Dengan kata lain, perkembangan lingkungan strategis Indonesia di LCS, tepatnya perairan Natuna Indonesia, memberikan identifikasi ancaman sumber daya laut dan pelanggaran hak berdaulat. Perencanaan nasional mengenai PMD, motivasi ideologis pemerintahan indonesia di bawah kepemimpinan Jokowi mendorong pentingnya menjaga kestabilan kawasan melalui kerjasama, serta menjaga kepentingan ekonomi sebagai pondasi utama kebijakan PMD sehingga pentingnya menjaga kestabilan 
kawasan untuk kegiatan ekonomi mendorong para pengambil kebijakan merumuskan strategi yang tidak bersifat provokatif dan cenderung menghindari terciptanya konflik yang berujung pada pengerahan kekuatan militer. Melalui langkah diplomasi, sebagai strategi, Indonesia mendorong penguatan hukum internasional sekaligus mempertegas kepada dunia internasional bahwa Laut Natuna Utara, berikut dengan perairan ZEE 200 mil, sebagai wilayah kedaulatan Republik Indonesia.

\section{Persaingan Amerika Serikat-Cina di Laut Cina Selatan dan Indo-Pasifik}

Laut Cina Selatan adalah penghubung penting dalam 'global commons', yang menghubungkan samudera Pasifik dengan samudera Hindia, Teluk Persia dan Eropa. Saat ini, bersama dengan Laut Cina Timur, itu adalah bagian laut yang paling diperebutkan di dunia (Jahangir 2020). Nilai strategis Laut Cina Selatan terletak pada kepentingan geopolitik yang tiap-tiap negara yang bergantung pada wilayah tersebut. Dengan kata lain, negara yang mampu memiliki pengaruh dan kontrol wilayah di indopasifik, akan memiliki jangkauan akses dan kontrol terhadap perilaku negara lain, serta kemampuan dalam memenuhi berbagai kepentingan politik yang strategis.

Laut Cina Selatan (LCS), sekilas, tampak seperti bagian lain dari lautan yang dikelilingi oleh gugusan pulau dan selat dan menutupi wilayah laut tertentu. Namun, kepentingan geostrategis dan ekonomi yang terkait dengan laut sangat besar dan berlipat ganda. Dari perdagangan maritim tersibuk hingga dasar laut yang penuh dengan sumber daya tak terbatas, bagian dari Samudra Pasifik ini bersinar dengan potensi supremasi geo-strategis dan ekonomi yang tak terbatas bagi siapa pun yang memiliki kekuatan untuk mendominasinya (Jahangir 2020). Di sisi lain, posisi LCS menjadi sangat relevan dengan motivasi dari Amerika Serikat (AS) dan Cina yang memiliki ambisi global dalam menentukan perubahan dan perkembangan keamanan global. Ambisi AS sebagai defender mendapatkan tantangan terbesar yang datang dari Cina sebagai the rising power, yang memiliki ambisi dalam mewujudkan kejayaan di masa lalu sebagai penguasa lautan. 
Amerika Serikat dan Cina berlomba untuk mendapatkan hegemoni di dunia multi-kutub yang berkembang di abad ke-21 (Jahangir 2020). Cina berupaya menjadikan LCS sebagai ruang bagi negara tersebut untuk menunjukkan dominasinya terhadap AS di wilayah Asia. Sementara AS, melalui pernyataan resmi pemerintah, kebijakan keamanan negara tersebut mendorong penguatan hukum internasional yang menekankan pada kebebasan navigasi. Tujuan dari dukungan terhadap hukum internasional oleh AS sangat sederhana, yaitu menutup ruang gerak dan dominasi politik dan militer Cina di wilayah tersebut.

Amerika Serikat menggunakan strategi aliansi dengan sekutuAustralia, Korea Selatan, dan terutama Jepang (Blumenthal 2020). Berbagai kompetisi yang tersaji dalam isu LCS mendorong kedua belah pihak untuk melakukan eksploitasi berbagai sumber daya nasional untuk meningkatkan kemampuan means masingmasing.

Namun, dalam beberapa tahun terakhir, prestasi inventif China telahmemungkinkannyamenciptakanlebih dari3.20ohektarlahan baru di Laut China Selatan. Hal itu berdampak pada peningkatan ketegangan politik dan keamanan, serta memungkinkan pasukan China untuk lebih mudah memproyeksikan kekuatan militer di seluruh wilayah (Blumenthal 2020).

Di isu berbeda, yaitu dalam perkembangan geopolitik di IndoPasifik juga terlihat persaingan AS dan Cina. Konflik dan kompetisi antar keduanya tersaji di wilayah tersebut. Samudra Hindia dan Pasifik telah menjadi tulang punggung perdagangan yang menggerakkan perekonomian Asia. Jaringan perdagangan dalam dua samudera ini menghubungkan Asia, Amerika Utara dan Selatan, Afrika, Eropa, dan Timur Tengah (Saeed 2017). Perairan di wilayah Indo-Pasifik mewakili arena yang semakin kritis untuk geopolitik maritim, keamanan, perdagangan, dan tindakan kebijakan lingkungan-isu-isu yang telah mengubah kawasan ini menjadi persimpangan utama hubungan internasional di mana Samudra Hindia dan Pasifik barat yang disatukan oleh arus sumber daya alam, rantai pasokan global, dan jaringan distribusi internasional. Pada saat yang sama, negara-negara pesisir IndoPasifik menghadapi kebijakan dan tantangan tata kelola yang signifikan dari berbagai sumber, termasuk sengketa wilayah dan persaingan di antara kekuatan angkatan laut, perebutan infrastruktur dan sumber daya kelautan dan pesisir, pembajakan 
dan perdagangan gelap di laut terbuka (Passarelli 2014). Adaptasi setiap negara pada berbagai kepentingan di wilayah maritim menjadi variabel yang mempengaruhi negara dalam menentukan arah kebijakan luar negeri di Indo-Pasifik.

Hal ini dipengaruhi oleh situasi dimana Indo-Pasifik adalah rumah bagi 10 dari 20 ekonomi dengan pertumbuhan tercepat; Indo-Pasifik saat ini mengandung lebih dari sepertiga PDB global dan 60 persen pertumbuhan PDB global; Pada tahun 2050, IndoPasifik diproyeksikan menyumbang lebih dari 55 persen dari PDB global, sebagian besar disebabkan oleh kelas menengah yang tumbuh; Omong-omong, 87 persen dari satu miliar pendatang kelas menengah berikutnya akan datang dari Indo-Pasifik; Dan pada tahun 2030, 65 persen dari kelas menengah dunia akan tinggal di Indo-Pasifik, mewakili jumlah daya beli yang tak tertandingi. Secara pragmatis, pasar potensial dan prospek ekonomi memberikan peluang selama semua negara, besar dan kecil, bekerja sama (Davidson 2019).

Kondisi itu sejalan dengan kebijakan strategis seperti negara Amerika Serikat tidak terlepas dari kepentingan nasional negara tersebut dalam mempertahankan pengaruh global sekaligus menghadapi kebangkitan Cina dan Rusia sebagai ancaman di kawasan Indo-Pasifik (Bhatt 2018). Perspektif AS di bawah kepemimpinan Obama, dan dilanjutkan Trump tetap menekankan pada strategi "poros" atau "penyeimbangan kembali" (Takahashi 2020). Perbedaaan mendasar dari keduanya terletak pada Obama yang lebih menekankan pada strategi militer yaitu pelibatan aliansi dalam Trans-Pacific Partnership (TPP), sementara Trump yang menarik diri dari TPP karena dinilai menjadi beban ekonomi, namun tetap berupaya menekan Cina dari sisi ekonomi.

Di sisi lain, China menjadi lebih tegas di Laut China Selatan sejak Xi Jinping menjadi Sekretaris Jenderal PKT pada tahun 2012. Xi Jinping menekankan pada pembangunan pulau Laut China Selatan sejak tahun 2017 dan ekspansi ke luar wilayah Cina sebagai bagian dari "maritime great power" yang coba dibangun negara tersebut. (Chubb, 2019).

Cina termotivasi untuk membangun kekuatan maritim yang dirancang untuk mencapai kepentingan ekonomi dan keamanannya. Cina, mencoba memimpin pengembangan ekonomi regional dan interkonektivitas, melanjutkan penggelaran 
angkatan laut dan membangun inisiatif ekonomi di Indo-Pasifik. Melalui konsep BRI, yang menjadi kebijakan geopolitik Cina. negara tersebut telah mengusulkan BRI pada tahun 2013 yang mencakup "Jalur Ekonomi Jalur Sutra" dan "Jalur Sutra Maritim abad ke-21," untuk membangun kembali Jalur Sutra kuno dengan menghubungkan Asia Tenggara dengan Afrika dan Eropa melalui pembangunan infrastruktur/pelabuhan di negara-negara sepanjang garis pantai (Saeed 2017).

Respon AS terhadap Cina diterapkan melalui The QUAD. The QUAD adalah aliansi atau sekutu AS di beberapa wilayah di Asia, terutama Asia Timur, Jepang, Asia Selatan yaitu India, dan di bawah Asia Tenggara, atau berdekatan dengan pasifik, yaitu Australia. Posisi strategis Jepang yang berdekatan secara geografis dengan Cina, mempermudah AS dalam melakukan perimbangan di wilayah Asia timur, sedangkan di samudera Hindia, India menjadi kekuatan yang dapat menghambat ekspansi Cina, dan Australia yang memiliki jangkauan dekat Pasifik memiliki kans besar dalam merespon secara cepat terhadap Cina.

Di sisi lain, penempatan kapal induk dengan fasilitas teknologi modern telah dikerahkan oleh Cina di Pasifik, dan peningkatan kapal selam kelas kilo terbaru dengan kualitas serangan terbaik dan kapal perusak modern yang dilengkapi dengan rudal dari Rusia. Semua kekuatan militer tersebut ditujukan untuk memperkuat posisi strategis Cina di Indo-Pasifik (Saeed 2017). Cina menempatkan kekuatan maritim untuk menghadapi negaranegara yang dianggap menentang perilaku negara tersebut, sementara langkah perimbangan menjadi opsi terbaik bagi AS dan sekutu dalam mempertahankan pergerakan Cina di Indo-Pasifik.

\section{Lingkungan Strategi, Ahli Siasat, Strategi, dan National Will}

Indonesia, AS, dan Cina merupakan negara yang banyak terlibat dalam berbagai interaksi konflik, dan kerjasama. Terutama AS dan Cina yang memiliki atmosfer konfliktual yang kental, sementara Indonesia lebih pada bentuk kerjasama. LCS dan Indo-Pasifik jelas menjadi wilayah yang memiliki nilai strategis. Hal itu tidak dapat dipungkiri masing-masing negara, namun nilai strategis kedua 
objek wilayah tersebut dilihat dalam perspektif yang berbeda oleh para pengambil kebijakan. Dengan kata lain, masing-masing negara melihat objek lingkungan strategis dalam yang sama, yaitu LCS dan Indo-Pasifik. Namun, masing-masing negara memiliki perspektif yang berbeda terhadap objek tersebut.

Presiden Joko Widodo atau Jokowi melihat LCS sebagai wilayah yang memiliki nilai strategis, terutama sumber daya laut dimana Zona Ekonomi Eksklusif (ZEE) Indonesia sepanjang 200 mil, berdasarkan Unclos 1982, di wilayah perairan Natuna. Dengan sumber daya laut yang besar, Indonesia dihadapkan pada klaim sepihak Cina melalui kebijakan Nine-Dash Lines yang mencakup hak berdaulat ZEE Indonesia. Ancaman illegal fishing dari berbagai negara, seperti Vietnam, Malaysia, dan terutama Cina merugikan Indonesia. Secara domestik, kebijakan Poros Maritim Dunia (PMD) yang dicanangkan Jokowi, menekankan pada eksploitasi sumber daya maritim serta kerjasama dan peningkatan ekonomi maritim dengan cara-cara damai atau diplomasi yang ditujukan dalam penyelesaian konflik. Dengan adanya ancaman di lingkungan strategis Indonesia, serta motivasi negara dalam menghadapi persoalan illegal fishing, terlihat bahwa national will Indonesia memang tidak mendorong pada hubungan konflik. Hal itu menyebabkan para pengambil kebijakan untuk melakukan diplomasi yang bersifat damai melalui penegasan wilayah Indonesia ke PBB untuk mempertegas posisi Indonesia di laut Natuna, dengan mengganti nama menjadi Laut Natuna Utara.

Berdasarkan pertimbangan tersebut, maka diplomasi menjadi opsi optimal bagi Indonesia. Di sisi lain, nilai strategis LCS dan Indo-Pasifik bagi AS dan Cina berjalan seiringan dengan motivasi ideologis atau national will kedua negara untuk meningkatkan pengaruh global melalui berbagai kebijakan geopolitik dan geostrategi. Perspektif para pengambil kebijakan sesuai dengan kepentingan politik dan motivasi negara untuk menjadi negara dengan pengaruh kuat di kawasan yang memiliki nilai strategis, terutama di kawasan Asia, dan wilayah yang menjadi tumpuan kegiatan ekonomi global.

Motivasi hegemoni mendorong pemimpin kedua negara untuk mempersiapkan berbagai kemungkinan konflik sebagai bagian dari kompetisi melalui kebijakan-kebijakan dalam menghadapi kemungkinan ancaman sekaligus persaingan yang ditujukan sebagai respon, baik perimbangan maupun langkah-langkah 
provokatif. Berbagai kebijakan politik, ekonomi, dan keamanan menjadi lebih agresif diterapkan, baik AS maupun Cina di LCS dan Indo-Pasifik. Perang dagang ekonomi, pengerahan kekuatan militer, pembangunan pangkalan militer, dan aliansi menjadi key feature dalam hubungan persaingan serta konflik kedua negara di dalam isu-isu politik dan keamanan internasional.

\section{Simpulan}

Penjelasan teoritis dari berbagai literatur tentang lingkungan strategis, ahli siasat, dan strategi menjadi dasar dalam tulisan ini dalam menggambarkan irisan dan keterkaitan ketiganya, terutama dalam menjelaskan isu-isu keamanan yang menjadi contoh. Dari penggambaran irisan dan keterkaitan antar ketiganya, terlihat bahwa ketiga variabel tersebut menjadi tahapan bagi para penstudi keamanan dalam menganalisa isu-isu keamanan internasional. Bahkan, ketiga variabel tersebut menyajikan sebuah pemahaman yang menekankan bahwa meskipun aktor-aktor negara berada pada lingkungan strategis yang sama, namun perspektif ahli siasat atau pemimpin atau para pengambil kebijakan dapat berbeda-beda dan menghasilkan strategi yang berbeda pula. Hal itu dipengaruhi oleh kondisi domestik sebuah negara, yaitu karakter national will negara tersebut. National will sebuah negara mendorong perumusan kebijakan yang disesuaikan dengan motivasi ideologis pemimpin atau negara. hal itu yang kemudian menjadi perbedaan besar dalam perumusan strategi setiap aktor negara, meski pemahaman mendalam tentang perumusan national will dan posisi pembentukan national will sebuah negara secara politik, ekonomi, militer maupun sosial-budaya bernegara setiap aktor masih belum dibahas secara mendalam. Berbagai faktor yang memungkinkan mempengaruhi pembentukan national will masih bersifat umum dan perlu dianalisis lebih lanjut. 


\section{Referensi}

\section{Buku dan Bab dalam Buku}

Allison, Graham T, 1971. Essence of Decision: Explaining the Cuban Missile Crisis, Boston: Little, Brown and Company.

Black, Jeremy, 2006. The Age of Total War 1860-1945, London: Praeger Security International.

Bondanella, Peter, 2005. Niccolo Machiavelli: The Prince, New York: Oxford University Press.

Buzan, Barry, 2003. Regions and Powers: The Structure of International Security, Cambridge: Cambridge University Press.

, 1987. An Introduction to Strategic Studies: Military Technology \& International Relations, United States of America: St. Martin's Press, Inc.

Chickering, Roger, (eds), 2005. A World at Total War: Global Conflict and the Politics of Destruction 19371947, Washington, D.C: German Historical Institute and Cambridge University Press.

Davidson, Phil, (2019) "Introduction to the Indo-Pacific Security Challenges," Journal of Indo-Pacific Affairs, Spring

Gray, Colin S, 2006. Strategy and History: Essays on Theory and Practice, New York: Routledge.

Hart, B.H. Liddel, 1967. Strategy, London: Faber \& Faber Ltd.

Kennedy, Robert F, 1971. Thirteen Days: A Memoir of the Cuban Missile Crisis, New York: W.W. Norton \& Company. 
Luttwak, Edward N, 2001. Strategy: The Logic of War and Peace, London: The Belknap Press of Harvard University Press.

Mintzberg, Henry. 2007. Tracking Strategy: Toward a general Theory, New York: Oxford University Press.

Price, John-Allen, 2008. Baron Antoine Henri de Jomini: The Art of War Restored Edition, Canada: Legacy Books Press.

Yarger, H, 2006. Strategic Theory For 21st Century: The Little Book on Big Strategy. Carlisle: Strategic Studies Institute.

\section{Jurnal}

Bhatt, Pooja, 2018. "Evolving Dynamic in the Indo-Pacific," Journal of Indo-Pacific Affairs.

Guillot, Michael W, 2003. "Strategic Leadership: Defining the Challenge," Air and Space Journal, Maxwel AFB: Winter, . Vol 17, Iss4.

Korkut, Ekrem and Kang, Woo Hyun, 2017. "China's Nine-Dash Line Claim in Light of the Ruling by the Permanent Court of Arbitration (12 July 2016)," 5 Penn. ST. J.L. \& International Affairs, 425.

McNerney, Michael J. 2018. "National Will to Fight," RAND Corporation, Santa Monica, Calif

Natasha, Hamilton-Hart. 2015. "Indonesia: Balancing the United States and Cina, Aiming for Independence," United States Studies Centre at the University of Sydney, November.

Passarelli, Ricky dan Michel, David. 2014. "Sea Change: Evolving Maritime Geopolitics in the Indo-Pacific Region," Stimson Center, December 
Saeed, Muhammad. 2017. "From the Asia Pasific to the IndoPacific," China Quarterly of International Strategic Studies, Vol. 3, No. 4, 499-512.

Suryadinata, Leo. 2017. "What Does Indonesia's Renaming of Part of the South China Sea Signify?," ISEAS Yusof Ishak Institute, No. 64.

Yuan, Jingdong. 2012. "Emerging Maritime Rivalry in South China Sea: Territorial Disputes, Sea-Lane Security, and the Pursuit of Power," International Security and Intelligence Bureau, University of Sydney, Australia, Summer.

\section{Artikel Daring}

Blumenthal, Dan, 2020."A South China Sea Strategy," [daring] dalam https://www.aei.org/a-south-china-sea-strategy/ [diakses 29 Agustus 2020].

Chapman, B. 2014. "China's Nine-Dashed Map: Maritime Source of Geopolitical Tension." Mackinder Forum Commentary. The Mackinder Forum. [daring] dalam http://www. mackinderforum.org/commentaries/china2019s-ninedashed-map-maritime-source-of-geopolitical-tension/ china2019s-nine-dashed-map-maritime-source-ofgeopolitical-tension [diakses 29 Agustus 2020].

Chubb, Andrew, 2019. "Xi Jinping and China's Maritime Policy," [daring] https://www.brookings.edu/articles/xi-jinpingand-chinas-maritime-policy/ [diakses 29 Agustus 2020].

Frank, Libor. 2003. "The Czech Republic Security Environment", [daring] dalam http://www.army.cz/mo/om/obrana a strategic/1-2003eng/frank.pdf [diakses 29 Agustus 2020].

Jahangir, Saamia, 2020. "The Strategic Importance of the South China Sea" [daring] dalam https://wgi.world/the-strategic- 
Asep Kamaluddin Nashir, Yugolastarob Komeini, \& Hesti Rosdiana

importance-of-the-south-china-sea/ [diakses 29 Agustus 2020].

Takahashi, Keikichi, 2020. "How Unique Is Trump’s

China Policy," [daring] dalam https://thediplomat. com/2020/06/how-unique-is-trumps-china-policy/ [diakses 29 Agustus 2020]. 
Strategic Environment, Strategist, and Strategy 